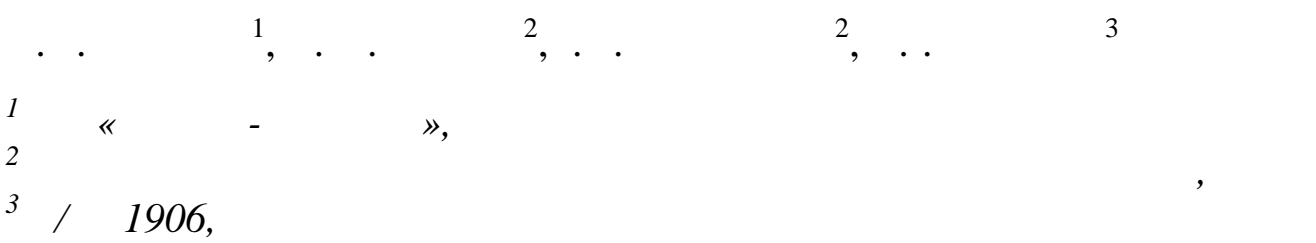

$-3003 " 1$

еред суч сних зр зків озброєння $m$ військової техніки ( ), які н дійшли у підрозділи ухопутних військ ( ) бройних ил кр їни ( ) окремо виділяється н віг иійн $n$ р тур спожив чів ( ) супутникових р діон віг ційних систем () $)$ GPS NAVSTAR -3003 " 3 льт". cm тті висвітлені основні $\quad m$ бойові можлливості, дн ох р ктеризов ні можсливі шляхи модерніз ції зр зків подібного кл су.

лючові слов : $\quad-3003$ " $з$ льт": $m$ ктичні можливості, технічні х р ктеристики, сутність роботи, скл дові п р тури, формуляри н віг ційного прийм ч .

\section{ступ}

т влення проблеми, н ліз досліджень і публік цій. сьогоднішній день пит ння удоскон лення н явних н віг ційних систем для н земних рухомих об'єктів, т кож створення нових, які поєднув ли б у собі одноч сно і супутникову р діон віг ційну компоненту, i втономну, є серед пріоритетних $[1,2]$.

к, у світі вже створені зр зки комплексов них н віг ційних систем ( ) для рухомих об'єктів [3-7], н с мперед 3 причин досягнення функціон льної 3 вершеності

, які вв ж ються основними н віг ційними з соб ми. тосовно іншої компоненти - втономної (з метою неперервності отрим ння н віг ційних п р метрів), то т кож $з$ вдяки досягненням у г лузі мікроелектроніки т кі н віг ційні системи $€$ м лог б ритними т цифровими, що уможливлює їх поєдн ння в єдиній п р тно-прогр мній ч стині.

кр їні процес створення перебув $є$ н

ст дії вироблення т ктико-технічних вимог до т ких систем, т кож н ст дії пошуку н йоптим льніших шляхів комплекс ції 3 ур хув нням ст ну н ціон льної економіки. дн 3 обов'язкових компонент комплексов ної н віг ційної системи виробник «ризон- віг ція» уже м є кільк в рі нтів свого викон ння і прийнят н озброєння бройних ил кр їни. той же ч с у відомих публік ціях [8-10] функціон льні можливості, технічні х р ктеристики, сутність роботи т структур н віг ційної інформ ції, що вид ється, опис ні явно недост тньо для того, щоб можн було б обгрунтов но висунути вимоги до створюв ної комплексов ної н віг ційної системи.

ме ост ннє і покл дене $з$ мету цієї ст тті д ти технічну оцінку н віг ційній п р турі -3003 " з льт" як основи для вироблення т ктико-технічних вимог до

\section{сновН Ч стин}

\section{г льн $\mathbf{x}$ р ктеристик н віг ційної} п р тури $\mathbf{- 3 0 0 3} "$ л льт". призн чен для втом тичного безперервного визн чення координ т місця (в т.ч. висоти н д рівнем геоїд бо еліпсоїд ), шляхової швидкості, н пряму руху т ч су UTC по р діосигн л х GPS $\mathrm{T}$ їх функціон льного доповнення SBAS (широкозонн диференційн систем ) у будь-якій точці земної кулі, будь-який момент ч су i нез лежно від метеоумов, індик ції поточних координ т т вид чі їх по ст нд ртному інтерфейсу зовнішнім спожив ч м.

ид н -3003 інформ ція скл д $\epsilon$ н віг ційні п р метри ( ), які можуть бути отрим ні в т ких систем х координ т: WGS-84,

-90.02, -95, -42, MGRS, UTM, у к ртогр фічній проекції усс, в системі, п р метри якої вводяться опер тором, тобто можливе отрим ння і геодезичних, i плоских прямокутних координ т. ри цьому для кутових д них допустимі форм т як гр дусної міри, т к i системи поділок кутомір, для інших тр диційні форм ти (км/год, м).

кож -3003 оцінює точність , i зокрем вр ховує модель іоносфери зі скл ду 
н віг ційного к дру GPS. ож оцінк прогнозов ної точності координ т $€$ зн ченням прогнозов ного середньокв др тичного відхилення ( ), вир женого в метр х. 3 лежить від кількості супутників, що беруть уч сть у визн ченні координ т, якості прийнятих сигн лів, розт шув ння супутників відносно спожив ч, від умов поширення н віг ційних сигн лів і похибки лгоритмів їх ур хув ння, т кож від виду і н явності диференційних попр вок.

ля з безпечення достовірності

п р тур

спожив ч здійснює вибір робочих (з оцінкою їх технічного ст ну) супутників т GPS,

т кож вр ховує прийняті диференційні попр вки. п м'ять для збереження можуть вводитися координ ти до 500 м ршрутних точок ( ), поточні координ ти як координ ти , до 50 м ршрутів, до 50 для кожного м ршруту, т кож льм н хи і GPS.

ідповід ючи критерію 6 г тофункціон льності, -3003 спроможн :

) розр ховув ти істинний зимут, дирекційний кут і відд ль від поточної точки до будь-якої з (між двом );

б) обмінюв тися інформ цією 3 зовнішніми систем ми т пристроями по цифровому інтерфейсу RS-232, причому п р метри швидкості, ч стоти обміну, типів сповіщень може 3 д в ти опер тор.

p диційно в т кій п р турі передб чені контроль функціонув ння, індик ція неспр вностей і розрядки кумулятор .

\section{p ктеристик т ктичних можливостей}

-3003 " з льт". п р тур -3003

3 безпечує розр хунок ч су прибуття в точку 3 визн ченими координ т ми при пересув нні 3 визн ченою швидкістю, розр хунок швидкості руху в визн чену точку з ч сом прибуття, візу льну сигн ліз цію про підхід н визн чену відст нь до точки 3 визн ченими координ т ми, обчислення п р метрів відхилення від визн ченого м ршруту при пересув нні т візу льну сигн ліз цію про вихід 3 межі допустимого відхилення від м ршруту.

інтерес х викон ння з вд нь підрозділ ми

i 3 допомогою -3003 можливі:

) перер хунок координ т (геодезичніпрямокутні; "гр дуси, мінути, секунди" - "гр дуси, мінути, ч стки мінут", "гр дуси, ч стки гр дус ", "поділки кутомір "; з зони в зону; з шестигр дусної зони в суміжну шестигр дусну зону);

б) обчислення і ;

в) визн чення кту льного ркуш к рти (вид ч його номенкл тури для з д ного пункту);

г) обчислення прямих, обернених i комбінов них з січок (з допомогою виміряних кутів, відд лей, спряженим спостереженням), інструмент льних ходів;

д) обчислення попр вки (в координ ті т висоті відносно пункту геодезичної мережі для отрим ння відкоригов них прямокутних координ т і висот при переміщення н точки, що прив'язуються);

е) строномічне орієнтув ння (розр хунок дирекційного кут орієнтирного н прямку 3 результ т ми спостереження світил ; скл д ння т блиць дирекційних кутів світил н 3 д ний період ч су для певних точок);

є) визн чення попр вки бусолі т перехід від м гнетного зимут до строномічного зимут , дирекційного кут т н вп ки;

ж) приведення до горизонту відст ней, виміряних 3 допомогою відд лемір т визн чення перевищення і висоти точки 3 н хиленою (горизонт льною) відд ллю т кутом місця (н хилу);

з) розр хунок коректур уст новок для стрільби пристрілюв нням з виміряними відхиленнями (спостереження зн ків розривів) і визн чення попр вок н відхилення умов стрільби від т бличних;

и) визн чення фронту, глибини т координ $\mathrm{T}$ центру р йону цілей 3 д ними координ т ми окремих об'єктів, розт шов них в ньому.

-3003 ст більно пр цює в ді п зоні темпер тур $-20 \ldots+50^{\circ} \quad 3$ відносної вологості $100 \%$ (для $25^{\circ} \mathrm{C}$ ).

ехнічні х р ктеристики -3003 - о н йв жливіших технічних х $\mathrm{p}$ ктеристик будь-якої н віг ційної системи н леж ть х р ктеристики щодо точності т ч су. -3003 з безпечує середню Кв др тичну похибку ( ) визн чення поточних зн чень $\mathrm{H}$ рівні до 20 м стосовно координ т місця і до 5 м їх же в диференційному режимі, до 0,1 м/с стосовно швидкості. мпульс прив'язується 3 до 100 нс в системі UTC.

-3003 прийм є сигн ли (по 24 к н л м) у ді п зоні L1 $(1575 \ldots 1616 \quad$ ц) для 3 кодом ст нд ртної точності н літер х від -7 до +12 , у ді п зоні L1 для GPS 3 код ми ст нд ртної точності т SBAS.

с першого визн чення - до 2 хв після ввімкнення живлення (в умов х відкритої місцевості), при н явності інформ ції льм н хів супутників - до 1 хв 3 моменту чергового ввімкнення п р тури.

искретність вид в ння (н індик цію т по інтерфейсу зовнішнім спожив ч м) - до 1 с.

с оповіщення про н явну відмову (під ч с тесту бо роботи) - до $10 \mathrm{c}$.

безпечення р діоелектронного $з$ хисту. к відомо, р діоелектронн обст новк є визн ч льним 
ф ктором н успіх бойових дій, тож пит ння p діоелектронної з хищеності (стійкості) технічних систем є вкр й в жливим.

ля $з$ стосов ної в -3003 нтени (див. рис. 3) досяжними є зн чення чутливості до перешкод, н ведені в т бл. 1, для поз нтенних к н лів прийому (кол живлення, керув ння), 3 лежно від смуги ч стот (в ц) - в т бл. 2.

блиия 1

утливість прийм ч до перешкод по основній нтені

\begin{tabular}{|l|c|c|}
\hline & $\begin{array}{c}\text { ідносн } \\
\text { чутливість }\end{array}$ & $\begin{array}{c}\text { ин мічний } \\
\text { ді п зон }\end{array}$ \\
\hline по бічному к н лу прийому & -60 д / т & $>50$ д \\
\hline $\begin{array}{l}\text { по блокув нню т } \\
\text { перехресним спотворенням }\end{array}$ & -10 д / т & $>75$ д \\
\hline по інтермодуляції & -40 д / т & $>55$ д \\
\hline
\end{tabular}

утливість прийм ч до перешкод по неосновних к Н л Х прийм ння

\begin{tabular}{|c|c|c|c|}
\hline муг ч стот & утливість & $\begin{array}{c}\text { муг } \\
\text { ч стот }\end{array}$ & утливість \\
\hline $0,01 \ldots 0,06$ & $\begin{array}{c}100 \\
\text { д /MK }\end{array}$ & $0,5 \ldots 6,0$ & 80 д /МК \\
\hline $0,06 \ldots 0,15$ & 90 д /MK & $6 \ldots 1000$ & 70 д /МК \\
\hline $0,15 \ldots 0,50$ & 86 д /Мк & & \\
\hline
\end{tabular}

воротне випромінюв ння (гетеродин ) н вході нтенного підсилюв ч - не більше 10 мк . р ктеристику р діоелектронної з хищеності п р тури у смузі перепуск ння ілюструє т бл. 3 . ивлення $\quad-3003 \in$ тр диційно урізном нітненим: від кумуляторного блок ( $)$, від зовнішніх джерел постійного бо змінного (через д птер) струму, від елементів живлення типу (через д птер). ри цьому споживч потужність п р тури - 3..5 т, у вип дку одноч сного з рядж ння $-15 \ldots 18$ т.

одо м си п р тури, то прийм ч у комплекті $3-1 \mathrm{kг,} \mathrm{нтен} \mathrm{-} \mathrm{0,5} \mathrm{кг,} \mathrm{д} \mathrm{птер} \mathrm{живлення} \mathrm{-}$ 1,9 кг, з рядний пристрій - 0,45 кг.

г льні принципи роботи п р тури. К відомо, супутников $\mathrm{p}$ діон віг ційн систем містить космічну т н земну компоненту, ост нню формують мереж керув ння т вл сне . ереж керув ння здійснює стеження 3 супутник ми, точно визн ч є орбіти і перед є д ні, що визн ч ють орбіту, кожному супутникові. супутник х перед в чі є точно синхронізов ними, з вдяки чому ними формуються одн кові 3 структурою р діосигн ли в той же ч с. з г льному вип дку структур бо код р діосигн лу $€$ псевдовип дковою послідовністю імпульсів блиця 3

р ничні зн чення рівнів перешкод, 3 яких пр цезд тність зберіг ється

\begin{tabular}{|c|c|}
\hline $\begin{array}{c}\text { р ктеристик орг нізов ної } \\
\text { перешкоди }\end{array}$ & $\begin{array}{r}\mathrm{p} \text { ничне } \\
\text { зН чення }\end{array}$ \\
\hline \multicolumn{2}{|c|}{ ежим стеження 3 сигн л ми } \\
\hline $\begin{array}{l}\text { ідношення рівня сигн лу до } \\
\text { рівня сум рної спектр льної } \\
\text { густини перешкоди т вл сних } \\
\text { шумів для прицільної шумової } \\
\text { перешкоди }\left(Q_{1}\right)\end{array}$ & 29 д \\
\hline $\begin{array}{l}\text { ідношення рівня синусоїд льної } \\
\text { перешкоди до рівня сигн лу }\left(Q_{2)}\right.\end{array}$ & 22 д \\
\hline $\begin{array}{l}\text { рмонічн перешкод н різних } \\
\text { ч стот х для } \\
\text { SBAS }\end{array}$ & $-140 \ldots-10$ д \\
\hline $\begin{array}{l}\text { умов перешкод в з лежності } \\
\text { від ширини спектр : } \\
\text { - до } 10 \text { к ц } \\
\text { - від } 10 \text { к ц для } \\
\text { - від } 10 \text { к ц для GPS, SBAS }\end{array}$ & $\begin{array}{l}-153 \ldots-149 \text { д } \\
-149 \ldots-136 \text { д } \\
-149 \ldots-122 \text { д }\end{array}$ \\
\hline $\begin{array}{l}\text { мпульсні р діоперешкоди } \\
\text { ді п зону } 1593 \ldots 1609 \text { ц з } \\
\text { трив лістю імпульсу } 125 \ldots 10^{3} \text { мКс } \\
\text { T шп рув тістю10 \% }\end{array}$ & 0 д \\
\hline \multicolumn{2}{|c|}{ ежим пошуку сигн лів } \\
\hline$Q_{1}$ & 37 д / ц \\
\hline$Q_{2}$ & 20 д \\
\hline $\begin{array}{l}\text { рмонічн перешкод н різних } \\
\text { ч стот х для } \\
\text { SBAS }\end{array}$ & \multirow{2}{*}{$\begin{array}{c}\text { н }-3 \text { д менше } \\
\text { відносно режиму } \\
\text { стеження }\end{array}$} \\
\hline $\begin{array}{l}\text { умов перешкод в з лежності } \\
\text { від ширини спектру }\end{array}$ & \\
\hline
\end{tabular}

( ). оді сигн л супутник містить промодульов ну кодом несучу т ефемеридну інформ цію (код супутник, відмітку ч су, координ ти супутник, льм н х (д ні для розр хунку розкл ду н ступних се нсів зв'язку з супутником, д ні про ст н супутник, службов інформ ція), коригуючі коефіцієнти).

обот грунтується н визн ченні ч су поширення р діосигн лу від супутник до прийм ч т обчисленні псевдовідд лі до супутник . прийм чі є генер тор ч стоти т кої ж

яку випромінює супутник. д ч поляг $€$ у досягненні рівності фз прийнятих т генер тор прийм ч шляхом зсуву фзи ост ннього. цьому р зі зн чення ч сової з тримки ф зи відповід тиме псевдовідд лі до супутник . відомими координ т ми супутник i псевдовідд ллю до нього визн ч ються координ ти прийм ч . дноч сно виділяється відмітк 
ч су, що порівнюється з відміткою ч су, виробленою .

розуміло, що для визн чення просторових координ т деякої точки необхідно зн ти відд ль від неї до трьох точок з відомими координ т ми (у н шому вип дку - супутник ми). е дозволяе м ти систему 3 трьох рівнянь 3 трьом невідомими (координ т ми нтени) [2].

зв'язку з спотвореннями сигн лу під ч с поширення $\mathrm{T}$ через інші причини слід т кож визн ч ти величину розбіжностей шк л ч су п р тури т супутник, для чого одержують виміри від дод ткового супутник . обто, для визн чення трьох координ т з ур хув нням розбіжностей шк л ч су необхідно м ти виміри щон йменше від чотирьох супутників однієї кщо використовуються одноч сно сигн ли від двох

(робот з зміш ним сузір'ям), то у зв'язку з невідповідністю шк л ч су GPS - UTC т

- UTC SU, кількість невідомих збільшується н одиницю, т , як н слідок, потрібні виміри від п’яти супутників.

ким чином, для визн чення своїх координ т п р тур повинн :

- точно вимірюв ти ф зу коду прийнятого сигн лу супутник ;

- прийм ти і декодув ти цифрову інформ цію, що перед є супутник (ефемериди і льм н х);

- визн ч ти ч с випромінюв ння сигн лу супутником;

- вир ховув ти точне місцезн ходження супутників н момент випромінюв ння прийнятого сигн лу;

- розр ховув ти псевдовідд ль до супутник т 3 цими д ними визн чити свої координ ти.

ісце точки спостереження може визн ч тися

бо бсолютним методом, бо диференційним.

бсолютним методом прийм ч обчислює свої координ ти в ре льному ч сі н основі інформ ції, одерж ної безпосередньо від супутник . ри цьому ре лізується тр диційний метод просторової лінійної з січки (прям геодезичн з січк) положення п р тури відносно супутник . иференційний (відносний) метод є точнішим 3 бсолютний. ін передб ч $є$ під ч с розр хунків координ т вр хув ння корельов ної в ч сі $\mathrm{T}$ просторі скл дової, яку слід компенсув ти (мір компенс ції з лежить від міри кореляції, чим ост ння вищ, тим вищ точність). ідповідні попр вки, які н зив ються диференці льними, прийм ються через порт RS-232, для чого використовується дод тковий прийм ч диференці льних попр вок (модем, MSK-прийм ч).

утність роботи п р тури $\mathbf{- 3 0 0 3}$.

втом тично здійснює пошук супутників, входження в зв'язок, визн чення і відобр ження координ т місця, ч су і вектор шляхової швидкості спожив ч . дноч сно з безпечує викон ння сервісних з вд нь, прийняття і облік диференційних попр вок, прийняття і вид чу інформ ції зовнішнім спожив ч м.

игн ли супутників прийм ються нтеною (рис. 1), підсилюються, фільтруються і н дходять н p діоприйм льний пристрій, в якому перетворюються н проміжну ч стоту в ді п зоні $18 \ldots 62$ ц, знову підсилюються т перетворюються у цифровий код окремо для кожної . лі сигн ли н дходять н обчислюв ч прийм ч для опр цюв ння ефемеридної інформ ції ( ). ід ч с цього i розв'язується н віг ційн 3 д ч, результ ти обчислень вид ються н дисплей, зовнішнім спожив ч м. ме цей обчислюв ч i визн ч $є$ псевдовідд ль до кожного спостережув ного супутник, порівнюючи вл сну т супутникову ч сові відмітки.

ерув ння -3003, вибір інформ ції, що виводиться н дисплей, введення д них т ком нд здійснюються опер тором 3 допомогою кл віш (рис. 2) прийм ч .

од тковими функціон льними з д ч ми є контроль н пруги живлення кумуляторного блок т оцінк ст ну 3 метою виявлення неспр вного блок, які проводяться п р лельно 3 основною роботою (з винятком перевірки прийм ч ).

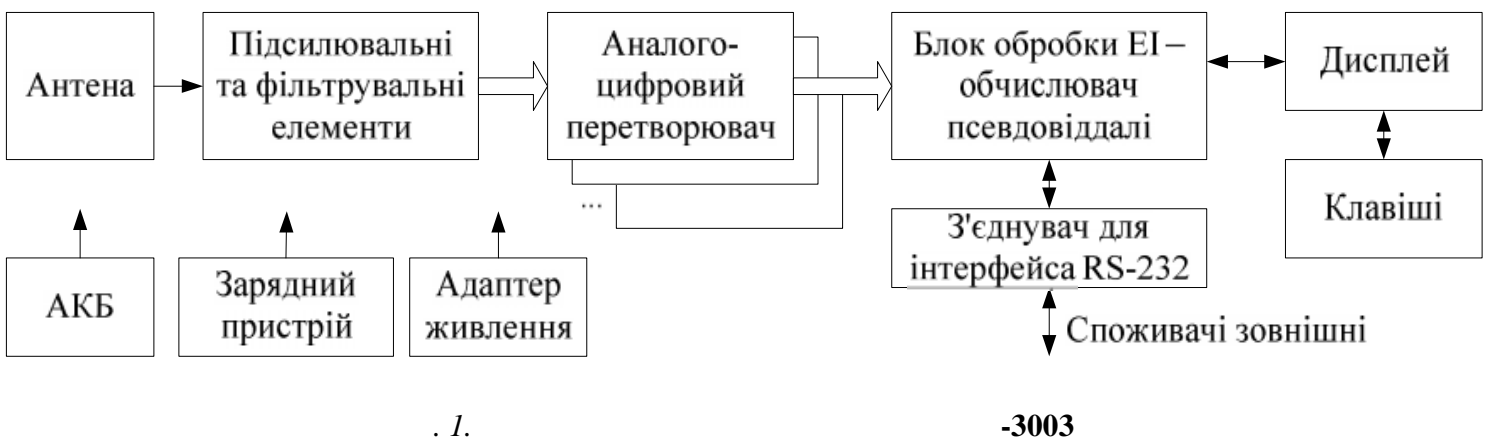

() . . одяних, . . имчук, . . ондр тюк, . . руднєв 


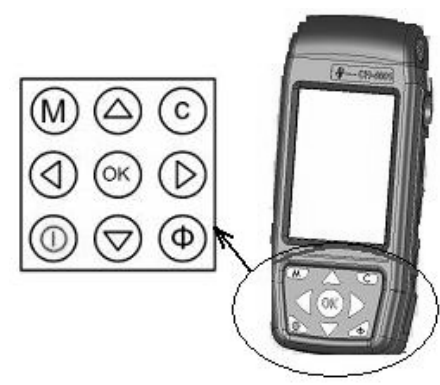

uc. 2. игляд прийм ч

т схем кл віш

керув ння

утність побудови т роботи скл дових п р тури $\quad \mathbf{- 3 0 0 3}$ • віг ційний прийм ч опр цьовує інформ цію супутників, відобр ж є результ ти обробки н дисплеї i перед $€$ iï зовнішнім спожив ч м по інтерфейсу RS-232.

онструктивно прийм ч містить: передню п нель, н якій розт шов ні кл ві тур т дисплей, вбудов ну нтену, пл ту прийм ч, вторинне джерело живлення н пругою $10 \ldots 30$, 3 дню п нель і кожух.

ункції кл віш керув ння (рис. 2) зведені до т бл. 4.

блиця 4

ункції кл віш керув ння

\begin{tabular}{|c|c|}
\hline иГ ЛЯД & ризн чення кл віш прийм ч \\
\hline & вмик ння / вимик ння живлення прийм ч \\
\hline$\gg$ & $\begin{array}{l}\text { підтвердження поч тку/з вершення будь-якої } \\
\text { дії; } \\
\text { виклик режиму ред гув ння п р метр ; } \\
\text { виклик контекстного меню для екр нної } \\
\text { сторінки }\end{array}$ \\
\hline «C» & $\begin{array}{l}\text { « ідмін »: } \\
\text { повернення н один рівень підменю вгору по } \\
\text { дереву меню; } \\
\text { відмін режиму ред гув ння без зберіг ння; } \\
\text { ск сув ння контекстного меню при його } \\
\text { ктив ції }\end{array}$ \\
\hline $\begin{array}{l}\gg, \\
»\end{array}$ & $\begin{array}{l}\text { перегляд п р метрів в режимі вибору; } \\
\text { пересув ння м ркер по позиціях пр воруч і } \\
\text { ліворуч в режимі ред гув ння; } \\
\text { втом тичне стир ння символів при кр йньому } \\
\text { лівому положенні відмітки ктивного символ }\end{array}$ \\
\hline $\begin{array}{l}\gg, \\
\gg\end{array}$ & $\begin{array}{l}\text { послідовне переміщення підсвічув ння рядк } \\
\text { чи поля п р метру вертик льно вгору бо вниз; } \\
\text { прискорений перебір символів бетки при } \\
\text { трив лій фікс ції кл віш в режимі вибору; } \\
\text { послідовний перебір всіх можливих зн чень } \\
\text { п р метру в режимі ред гув ння }\end{array}$ \\
\hline$\ll \gg$ & $\begin{array}{l}\text { « ікс ція»: виклик сторінки формуляр } \\
\text { « бір сm тистики» }\end{array}$ \\
\hline$\ll$ & $\begin{array}{l}\text { « еню»: } \\
\text { виклик головного меню прийм ч ; } \\
\text { виклик контекстного меню для формулярів } \\
\text { керув ння б з ми д них ( рхів м ршруту руху, } \\
\text { рхів контурних точок) }\end{array}$ \\
\hline
\end{tabular}

ндик тором є рідинно-крист лічний дисплей з роздільною зд тністю $240 \times 320$ пікселів. ін 3 хищений від уд рів з хисним склом.

нтенний блок (зовнішня нтен ) прийм є т підсилює сигн ли т GPS у ді п зоні L1. сновні нтени зведені до т бл. 5.

блиця 5

ехнічні х р ктеристики нтени

\begin{tabular}{|c|c|}
\hline і п зон робочих ч стот, & $1570 \ldots 1608$ \\
\hline $\begin{array}{l}\text { оефіцієнт стоячої хвилі н пруги } \\
\text { виходу }\end{array}$ & до 2 \\
\hline оефіцієнт підсилення, д & $25,0 \pm 2,5$ \\
\hline оефіцієнт шуму, д & до 3,5 \\
\hline $\begin{array}{l}\text { оефіцієнт підсилення нтенного } \\
\text { випромінюв ч (відносно ізотропного } \\
\text { випромінюв ч } 3 \text { круговою } \\
\text { поляриз цією) для кутів місця } \\
90^{\circ} / 50 \ldots 90^{\circ} / 15 \ldots 50^{\circ} / 5 \ldots 15^{\circ}, \text { д }\end{array}$ & $\begin{array}{c}\text { від } \\
2 / 0 /-4 /- \\
7\end{array}$ \\
\hline пруг живлення, & $2,75 \ldots 5$ \\
\hline трум спожив ння, м & до 30 \\
\hline
\end{tabular}

і гр м спрямов ності нтени з безпечує одноч сне прийм ння сигн лів н 3 д них ч стот $\mathrm{X}$ у верхній півсфері у секторі кутів місця 5...175․

онструктивно нтенний блок викон но окремим блоком (рис. 3) - його основ і корпус виготовлені 3 люмінієвого спл ву і м ють струмопровідне г льв нічне покриття.

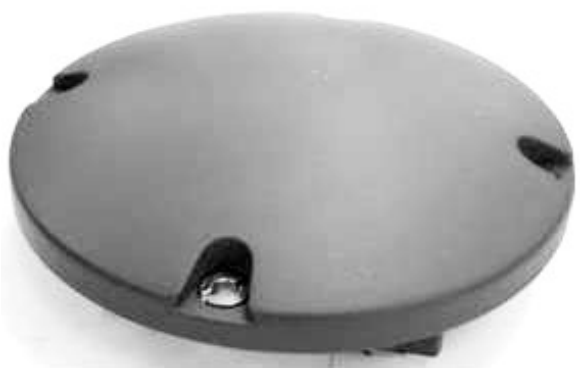

uc. 3. игляд нтенного блок

кумулятор використовується для роботи в польових умов х і з безпечує номін льну вихідну н пругу 7,2 з номін льної ємності 2 год.

ряджений кумуляторний блок з безпечує безперервну роботу -3003 в норм льних клім тичних умов $\mathrm{x}$ не менше 8 годин. рядж ння кумуляторного блок уможливлено через з рядний пристрій, який живиться від бортової мережі постійного струму бо через д птер від мережі змінного струму 220,50 ц. 
онструктивно блок скл д ється 36 кумуляторних б т рей типу Panasonic HHR200A, які м ють ємність не менше 2,0 год, об'єдн них в блок і розміщених в нерозбірному мет левому корпусі з конт ктною групою для підключення до прийм ч .

рядний пристрій ( ) здійснює з рядж ння кумуляторного блок в режимі прискореного 3 рядж ння 3 4...5 год. 3 н ступним дод тковим 3 рядж нням у режимі з рядж ння м лим струмом.

ехнічні х р ктеристики пок з ні у т бл. 6 .

блиия 6

ехнічні х р ктеристики 3 рядного пристрою

\begin{tabular}{|c|c|}
\hline пруг живлення , & $10,8 \ldots 29,7$ \\
\hline $\begin{array}{c}\text { трум з ряду, що вид ється н } \\
\text { кумуляторний блок, }\end{array}$ & $0,6 \pm 0,1$ \\
\hline $\begin{array}{c}\text { пруг , вироблен , для живлення } \\
\text { мікросхеми контролю темпер тури, } \\
\text { вбудов ної в кумуляторний блок, }\end{array}$ & $5,0 \pm 0,5$ \\
\hline пожив н потужність, т & до 15 \\
\hline
\end{tabular}

овнішній вигляд пок 3 но н

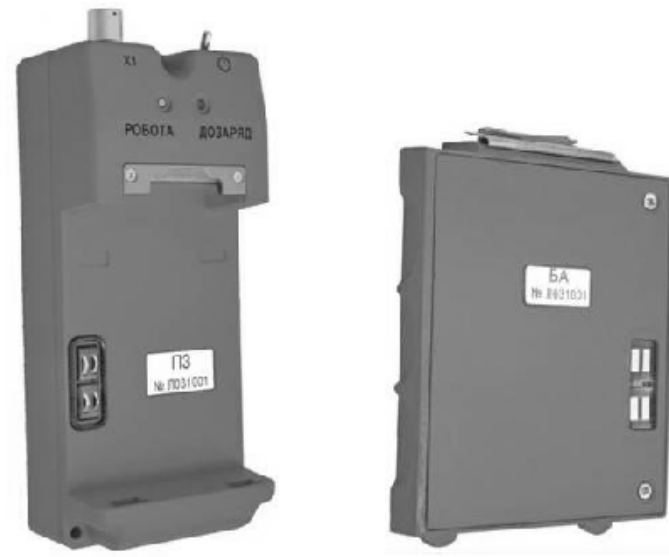

uc. 4. игляд 3 рядного пристрою т кумуляторного блок

д птер мережі живлення перетворює змінну н пругу мережі 220 , 50 ц в постійну н пругу $12,0 \pm 0,6$ для живлення прийм ч в ст ціон рних умов х, т кож для живлення з рядного пристрою під ч с з ряду кумуляторного блок . ого споживч потужність - до 35

пис роботи 3 формуляр ми. ормуляром н зив ють перелік п р метрів т функцій, необхідних для викон ння 3 д ч 3 призн ченням п р тури -3003 . ормуляри умовно згрупов ні: одн груп $\epsilon \mathrm{K}$ тегорією інформ ційних екр нів для відобр ження в ре льному ч сі д них поточних н віг ційних визн чень, інш - к тегорією ді логових екр нів для інтер ктивної роботи користув ч 3 прийм чем. оступ до ост ннього формуляр - через систему вкл дених меню.

кл д д них, які виводяться н дисплей у формуляр $\mathrm{x}$, оптимізов но, що дозволяє користув тися ктивною зоною дисплея (в окремих вип дк х передб чен прокрутк ). рикл ди сторінки екр н т ї̈ под льшого розгорт ння пок 3 ні н рис. 5,6 .

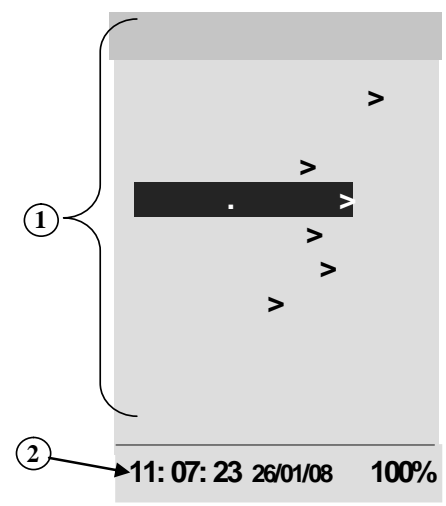

uc. 5. игляд формуляр

:

зон 1 - для оригін льної для кожного формуляр (екр нної сторінки); зон 2 -для 3 г льної інформ ції для усіх формулярів (поточногоч су, д ти, індик тор з ряду )

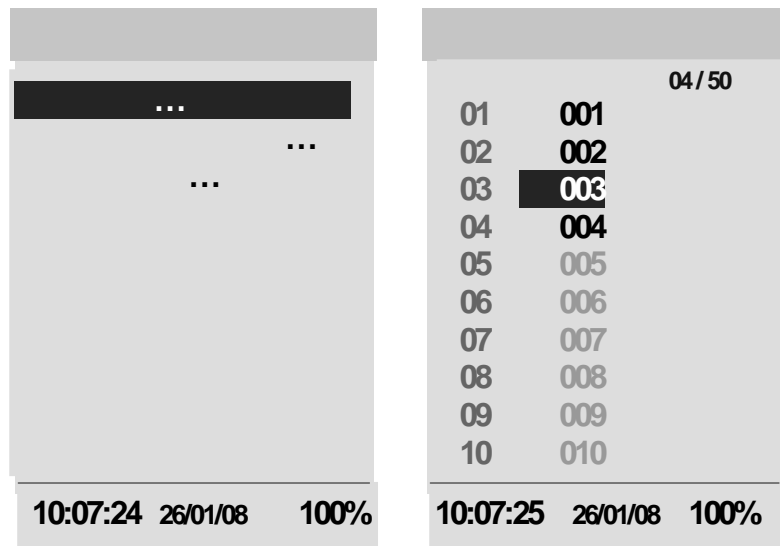

uc. 6. ункти вкл деного меню

т бл. 7 зведені скл дові меню (формулярів) н віг ційного прийм ч (символ ">" пок зує продовження по дереву меню, символ "..." відкрив ння однойменної екр нної сторінки, відсутність символ - пункт меню є н звою функції, що ктивується при його виборі).

(C) . . одяних, . . имчук, . . ондр тюк, . . руднєв 
блиия 7

міст формулярів н віг ційного прийм ч

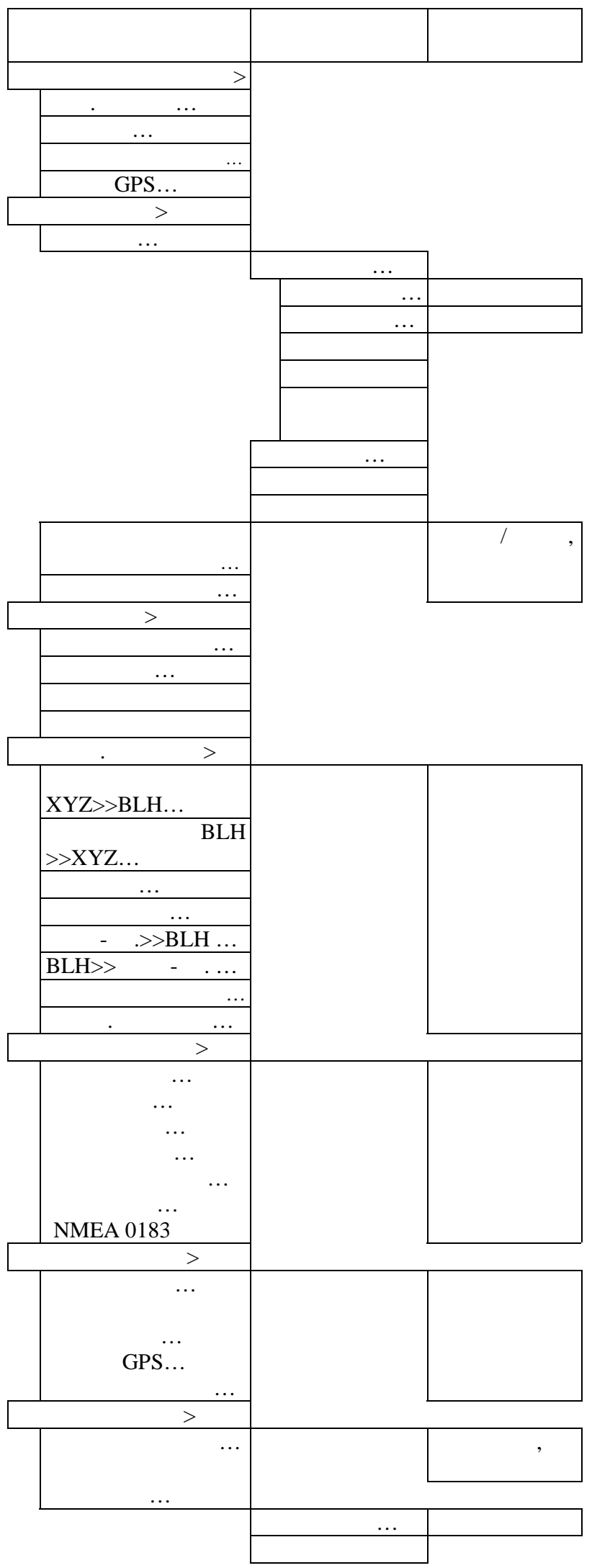

\section{ИСН ОВ К И}

под льших дослідженнях слід розглянути структуру формулярів, які використовуються в п р турі -3003, т кож про н лізув ти вид вихідної інформ ції н віг ційного прийм ч 3 позиції ¥і1 використ ння у комплексов ній н віг ційній системі. кож доцільним $\epsilon$ обгрунтув ння структури комплексов ної н віг ційної системи для вип дку, коли однією 3 компонент є п р тур типу -3003. розуміло, що до н віг ційної компоненти можуть бути висунуті дод ткові вимоги, зокрем можливість вид в ння координ т у системі $\quad-2000$ тощо.

\section{писок літер тури}

1. озробк проекту рогр ми створення і розвитку системи н віг иійного з безпечення бройних ил кр їни : [звіт про н ук.-досл. роб. „, омп с"] - . : , 2009. - [ нв. №208- ]. - $115 \mathrm{c}$

2. орольов . ехнічні вимоги до н віг ційної інформ ції $m$ суч сних систем н віг иії н земних рухомих об'єктів / . орольов $m$ інші // уч сні досягнення геодезичної н уки т виробництв : [зб. н ук. nр.] - ьвів: іг - рес, 2003. - № 8. - .218-221.

3. офм нн- елленгоф, ег $\mathrm{m}$, ізер. віг ція. снови визн чення місцеположення $m$ скеровув ння. $\therefore \quad$ iм. . $\quad$ р нк, 2006.

4. іляшкін . нериі льно-супутникові н віг ційні системи: н вч. посібник / . іляшкін, . огожин. - .. , 2009. $-272 c$

5. Santiago Alban. An Inexpensive and Robust GPS/INS Attitude System for Automobiles [ лектронний pecypc] / A. Santiago. - ехсим достуnу http://waas.stanford.edu/ wwu/papers/gps/PDF/albanIONGP S02.pdf.

6. Brown A. Navigation Using LINK-16 GPS/INS Integration [ лектронний ресурс] / A. Brown, P. Sack // Proc. of ION GPS/GNSS, (Portland, OR, Sept.2003).- ежсим docmyny : http://www.navsys.com/Papers/0309001.pdf.

7. Elkaim G. Comparison of Low-Cost GPS/INS Sensors for Autonomous Vehicle Applications / G. Elkaim, M. Lizarraga, L. Pedersen. - eжим docmyny : http://users.soe.ucsc.edu/ elkaim/Documents/ImuCompPLAN S08.pdf.

8. виг иионный комплекс "з льт- " [ лектронний ресурс] / еоінформ ційний порт л. ежим доступy : http://www.orizon-navigation.com.

9. віг иійне з безпечення військ : довідник / [. гмет, . іхно, . стушенко, . щук $m$ ін.]$\therefore \quad$ 2005. $-372 c$.

10. 3 ков . . віг ційн $n$ р тур для систем моніторингу і контролю иілісності сигн лів супутникових н віг ційних систем - $C$ " - »/ . 3 ков, . одяних // истеми упр вління, н віг ції $m$ зв'язку. 2008. - un. 1(5). - .15-19.

дійшл до редк кцї̈ 14.10.2010 p.

ецензент: доктор технічних н ук, ст рший н уковий співробітник . . орольов, уковий центр ухопутних військ, ьвів. 
. одяных, . . ымчук, . . ондр тюк, . . руднєв

виг ционн $я$ пn р тур потребителя спутниковых $p$ дион виг иионных систем является одним из высокотехнологических обр зиов систем вооружения, принятых в последнее время н вооружение ухопутными войск ми кр ины. $m$ тья освеш ет основные этой пп р туры, ее боевые возможсности и особенности эксплу т иии с иелью обоснов ния путей объединения р ссм трив емой спутниковой н виг иионной компоненты с инерци льными средств ми н виг иии в единой технической ре лиз ции.

лючевые слов : $\quad-3003$ " $з$ льт": $m$ ктические возможности, технические х р ктеристики, сущность р боты, сост вные пn р туры, формуляры н виг ционного приемник.

\title{
TECHNICAL DESCRIPTION OF SN-3003 "BAZALT" NAVIGATION SYSTEM
}

\author{
. . Vodianyh, V.Yu. Tymchuk, I.O. Kondratiuk, D.I. Zarudniev
}

SN-3003 "Bazalt" is one of highly technological military equipment of Armed Forces of Ukraine. SN-3003 "Bazalt" is a receiver of signals of GPS and GLONASS satellite radionavigational systems. In the paper the technical aspects of this equipment, its combat capabilities exploitation peculiarities aimed at modernization of this system to create the integrated navigational system are highlighted.

Keywords SN-3003 "Bazalt": tactical possibilities, technical descriptions, essence of work, component apparatuses, formulary of navigation receiver.

629. 1113. 01

. . p йник, . . олош нський

“ кр їнський інститут втобусо - тролейбусобудув ння”, ввів

: 041,

роведено огляд $i$ н ліз суч сних 6 г тоцільових в жкких військових джипів, які ст новлять до 50\% втоп рку суч сних рмій. редст влено проект вітчизняного н лог в иьомукл сі-мод. 031 , в нт жопідйомністю $1,5 \mathrm{~mm}$ його основні технічні х $р$ ктеристики..

лючові слов : джсип, 6 г тоцільовий, в жккий, технічні х р ктеристики.

\section{ступ}

егкові повноприводні рмійські втом шини, які н були м сового розповсюдження з ч сів ругої світової війни, ст новлять більше $50 \%$ з г льної чисельності втоп рків суч сних рмій, зокрем кр їн [1].

р ктично ще з 1941-42 років відбувся поділ цих м шин н 3 к тегорії - 3 лежно від в нт жопідйомності:
- кл с 1/2 т (Willys, MB, Ford GPW - пон д 630 тис. штук у 1941-1945 рок х, 64-67 - 5,3 тис., VW82 (Kuebelwagen) - 50тис.шт.);

- кл с 3/4т (Dodge WC 56 -35,6 тис.шт. 3 194245 років, Humber FWD - 6,5 тис.шт. у еликобрит нії, ofch 901, Steyr 1500 - в імеччині;

- кл с 1,5 т (ком ндно-шт бні м шини верм хту н ш сі 1,5-тонних повноприводних рмійських в нт жівок MAN, MB, Steyr). 